\title{
Plasmid distribution in European Diaporthe helianthi isolates
}

\author{
Mariarosaria Vergara ${ }^{1,2}$, Tiziana Capasso ${ }^{1}$, Emanuela Gobbi ${ }^{3} \&$ Giovanni Vannacci $^{1}$ \\ ${ }^{1}$ Dipartimento di Coltivazione e Difesa delle Specie Legnose "G. Scaramuzzi", Sez. Patologia Vegetale, Via \\ del Borghetto 80, 56124 Pisa, Italy; ${ }^{2}$ Scuola Normale Superiore di Pisa, Piazza dei Cavalieri 7, 56100 Pisa, \\ Italy; ${ }^{3}$ Dipartimento di Biologia Applicata alla Difesa delle Piante, Università di Udine, Via Scienze 208, \\ Udine I-33100, Italy
}

Received 1 September 2004; accepted in revised form 27 January 2005

\begin{abstract}
Diaporthe helianthi is the causal agent of sunflower stem canker, a serious pathogen of sunflower in Europe, which has been sporadically recorded in Italy. A collection of 26 Diaporthe helianthi isolates deriving from different geographic origins was analysed in order to determine the presence of extra-chromosomal genetic determinants and their molecular diversity. Extra-chromosomal bands in total genomic DNAs were identified in every French and the Yugoslavian isolate and in only one Italian isolate, while no Romanian and Argentinean isolates resulted to host any plasmids. When tested for their chemicophysical nature, they were recognised as linear plasmids sized about $2.3 \mathrm{~Kb}$. A more detailed analysis was performed on a plasmid purified from a French isolate (plasmid F). Its intracellular localisation resulted as mitochondrial. Plasmid $\mathrm{F}$ was also exploited as a probe in Southern hybridisation experiments, in which it recognised only plasmids present in the genomes of French and Yugoslavian isolates (countries were the disease has a heavy incidence) indicating a strong correlation to geographic origin. An RFLP hybridisation analysis performed on genomic DNAs revealed a homogeneous restriction pattern in all French and Yugoslavian isolates, suggesting molecular homology among plasmids present in those isolates.
\end{abstract}

Key words: diaporthe helianthi, geographic origin, genetic variability, plasmids

\section{Introduction}

Plasmids of filamentous fungi have frequently been found in cultures derived from natural populations. The study of the biology of natural plasmids may help to investigate their properties, since they are useful markers for population studies in fungi [1] and potential tools for developing vectors, such as in bacteria [2,3]. Regarding their intracellular localisation, most fungal plasmids are mitochondrial. Only a few examples of cytoplasmic plasmids are known in filamentous fungi [4]. From a structural point of view, plasmids may be circular or linear [5]. Circular plasmids, documented for the most part in Neurospora spp. [1], have varying origins and are found as unique sequences, while linear plasmids belong to a homogeneous group with respect to replication, function and sequence, suggesting that they descend from a common ancestor [6]. Circular forms of mitochondrial plasmids often represent defective forms of mitochondrial DNA (mtDNA), autonomously replicating as Podospora anserina plDNA [7], with few exceptions, such as Neurospora Mauriceville, Varkud, Fiji and LaBelle and Cryphonectria parasitica pUG1, whose sequences are independent of mtDNA. Natural plasmids occurring in filamentous fungi usually are linear, localised in mitochondria, and are mostly "true plasmids" lacking any homology to the mtDNA [8]. Up till now, only in a few examples a function has been attributed to a fungal plasmid. 
The functions of most linear plasmids are still unclear, with a few exceptions such as the Neurospora spp. kalilo and maranhar associated with senescence, the Ascobolus immersus PAI2 [9] and the Podospora anserina pAL2-1 involved in an increased life span [10]. In the phytopathogenic fungus Cryphonectria parasitica, the circular mitochondrial plasmid pUG1 occurs in virulent strains exhibiting a senescent phenotype [11]. An almost homogeneous family of mitochondrial plasmids related to pUG1 has spread among the North American and European $C$. parasitica populations [12]. Since plasmids have been frequently reported in phytopathogenic fungi, their possible involvement in pathogenicity mechanisms has been considered. A circular plasmid occurring in Rhizoctonia appears to correlate to host specificity [13]; in Rhizoctonia strains with low pathogenicity a cytoplasmic linear plasmid has been isolated [14]; in Fusarium oxysporum f. sp. lycopersici another circular plasmid has been associated to nitrofuran resistance [15]; a linear mitochondrial plasmid with a role in races pathogenicity has been identified in Fusarium oxysporum f. sp. conglutinans [16]. There are reports of several mitochondrial linear plasmids in other phytopathogenic fungi, such as Pyrenophora graminea [17] and Claviceps purpurea [18].

Diaporthe helianthi Munt.-Cvet. et al. (anamorph Phomopsis helianthi Munt.-Cvet. et al.) is the causal agent of sunflower stem canker, a widespread disease in Europe, where it causes serious economic damage. It first appeared in the former Yugoslavia in the late 1970s [19] and then became one of the most widely diffused diseases of the cultivated sunflower [20]. Heavy yield losses have been reported in France and in the former Yugoslavia, where environmental conditions are conducive to infection [21, 22]. In Italy, the disease was first recorded in 1987 [23], but since then the pathogen has appeared only sporadically and does not cause significant yield losses, despite the fact that climatic conditions are conducive to an epidemic outbreak of the disease [24]. The lack of such epidemics in Italy may be due to different pathogen populations occurring in the country.

Intraspecific variability has been previously displayed by different $D$. helianthi isolates, which have been studied by several approaches. In the early 1980s, Yugoslavian D. helianthi isolates have been screened for morphological, biological and epidemiological differences [25]; then European populations have been analysed for morphophysiological and genetic characters [26, 27]. The interaction between French $D$. helianthi isolates and varyingly susceptible sunflower cultivars has been investigated [28]. Molecular genotypic and phenotypic variability within the Diaporthe/ Phomopsis helianthi complex in a French population has been reported by means of amplified fragment length polymorphisms (AFLP) and ITS sequence analysis [29]. The first comparison among different populations of $D$. helianthi showed variations in vegetative compatibility, isozyme patterns and morpho-physiological characters that correlated to geographic origin [30]. A later study investigated a collection of $26 \mathrm{D}$. helianthi isolates of different geographic origin (14 from France, 3 from former Yugoslavia, 3 from Argentina, 1 from Romania and 5 from Italy) using different approaches to evaluate their molecular diversity. The ribosomal intergenic spacer (IGS) revealed intraspecific variability within a homogeneous group including French and Yugoslavian isolates, while Italian isolates displayed a high heterogeneity [31]. The same trend was displayed through polymorphisms in the nuclear ribosomal internal transcribed spacer (ITS) and in mitochondrial regions [32], through randomly amplified polymorphic DNA (RAPD) markers [33], phenotypic characters such as mycelial isozymes [34] and a nuclear coding region homologous to a polyketide synthase gene [35]. All data relative to that set of $D$. helianthi isolates suggest the presence of a polyphyletic clade of isolates occurring in Italy, as opposed to a monophyletic cluster of French and former Yugoslavian isolates, within the Phomopsis/Diaporthe complex, thus supporting the hypothesis that genetically different biotypes are present in countries where the disease exhibits a different epidemiology.

A preliminary analysis of the presence of plasmids in those $D$. helianthi populations has been previously reported [36]. In order to correlate the presence of plasmids, the geographic origin and genetic biotypes inside the same set of $D$. helianthi isolates, this study surveyed the occurrence of extra-chromosomal genetic determinants. In the present work the detection and partial characterisation of $D$. helianthi linear plasmids is reported for the first time and their presence is associated with the geographic origin of fungal isolates. 


\section{Materials and methods}

\section{Fungal isolates and culture conditions}

Table 1 lists all 26 Diaporthe helianthi isolates collected from different geographical areas and isolated from diseased plants. Fungal isolates were grown at $24{ }^{\circ} \mathrm{C}$ under $12 / 12 \mathrm{~h}$ light cycles on PDA (potato dextrose agar, Difco, USA) plates and stored under mineral oil at $4{ }^{\circ} \mathrm{C}$. When needed, liquid cultures were set up at room temperature with $150 \mathrm{rpm}$ shaking in a modified Fries medium [37] supplemented by $0.5 \%$ yeast extracts.

\section{Genomic DNA isolation}

Samples were harvested from five-day-old mycelium, collected from agar plates covered by a film of cellophane or from filtered liquid cultures, and lyophilised. Total genomic DNA was extracted by a modified SDS-CTAB method [38]. DNA samples were dissolved $(50 \mathrm{ng} / \mu \mathrm{l})$ in sterile water and stored at $-20{ }^{\circ} \mathrm{C}$ until use. Agarose gel electrophoresis was performed in a TAE buffer $(40 \mathrm{mM}$ Tris-acetate, $2 \mathrm{mM}$ EDTA); $1 \mathrm{~Kb}-\mathrm{DNA}$ ladder (Invitrogen, The Netherlands) was used as a molecular weight marker.

\section{DNA III-exonuclease and proteinase $K$ digestions}

DNA III-exonuclease digestion: $3 \mu \mathrm{g}$ of genomic DNA were treated for $2.5 \mathrm{~h}$ at $37{ }^{\circ} \mathrm{C}$ with IIIexonuclease $1 \mu \mathrm{l}$ (65 Units/ $\mu \mathrm{l}$, Invitrogen, The Netherlands) in a total volume of $15 \mu \mathrm{l}$ with the commercial buffer; $1 \mu \mathrm{g}$ of phage DNA served as a positive control.

Proteinase $K$ treatment: genomic DNAs ( $3 \mu \mathrm{g}$ each) were digested by $100 \mu \mathrm{g} / \mathrm{ml}$ proteinase $\mathrm{K}$ (Sigma, USA) for 1 hour at $37^{\circ} \mathrm{C}$ in $50 \mathrm{mM}$ Tris$\mathrm{HCl} \mathrm{pH} \mathrm{7.5,} 10 \mathrm{mM} \mathrm{CaCl}_{2}, 1 \%$ SDS and then ethanol precipitated.

\section{Isolation of mitochondria and mtDNA}

A modified version of Taylor and Natvig's protocol [39] was applied. Fresh mycelium, obtained from a 7-day-old liquid culture of the isolate 101/ 96, was ground in a cold extraction buffer (10 mM TES-NaOH pH 7.5, $10 \mathrm{mM}$ EDTA $\mathrm{pH} 8,0.33 \mathrm{M}$ sucrose) and centrifuged to obtain a mitochondria-enriched pellet. After a discontinuous two steps (1.6 and $1.2 \mathrm{M}$ ) sucrose gradient, mitochondria were recovered from the 1.6-1.2 M interface, washed and then digested by $50 \mu \mathrm{g} / \mathrm{ml}$ DNAse I (grade II, Roche Diagnostics, Germany). mtDNA was isolated in $100 \mathrm{mM}$ Tris$\mathrm{HCl} \mathrm{pH} 8.2,150 \mathrm{mM} \mathrm{NaCl}, 1 \mathrm{mM}$ EDTA, supplemented with $100 \mu \mathrm{g} / \mathrm{ml}$ proteinase $\mathrm{K}$ and $10 \%$ sarkosyl. The sample was then incubated for $30 \mathrm{~min}$ at $65^{\circ} \mathrm{C}$, centrifuged for $10 \mathrm{~min}$ at $5200 \times g$, extracted with phenol/chloroform and ethanol precipitated.

\section{Purification and restriction mapping of plasmid DNA}

The plasmid F DNA was purified from the total genomic DNA extracted from the isolate 101/96. The band was excised from agarose gel, eluted and purified using the commercial gel extraction kit NucleoTrap ${ }^{\circledR}$ (Macherey-Nagel, Germany), following the manufacturer's instructions. For restriction tests each enzyme, ApaI, CfoI, EcoRI, HaeIII, Hsp92II, MspI, PstI, RsaI, SacI and SalI (Promega, USA), was incubated with purified plasmid DNA.

\section{Non-radioactive Southern blot and RFLPS}

For the Southern blot experiments all steps were performed according to the Roche DIG System Guide. The probe (plasmid F) was digoxigeninlabelled by random priming (DIG DNA Labeling kit, Roche, Germany). Hybridisations were carried out in $50 \%$ formamide for $16 \mathrm{~h}$ at $42{ }^{\circ} \mathrm{C}$; the membranes were then washed in $0.5 \times \mathrm{SSC}$ at $60{ }^{\circ} \mathrm{C}$ [40]. A chemiluminescent detection was performed (DIG DNA Detection Kit, Roche, Germany).

For RFLP analysis, genomic DNAs (5 $\mu \mathrm{g}$ each reaction) were digested by each restriction enzyme, CfoI, HaeIII, Hsp92II, MspI (Promega, USA). Southern blot experiments on restricted samples were performed as already described.

\section{Results}

Detection of extrachromosomal elements in genomic DNAs

When total genomic DNAs, extracted from Diaporthe helianthi isolates originating from 
different geographic regions (Table 1), were submitted to electrophoresis, extra bands each sized about $2.3 \mathrm{~Kb}$ appeared in 18 out of $26(69 \%)$ fungal isolates. The presence of extrachromosomal elements correlated to the geographic origin of the fungal strains: 14 out of 14 French $(100 \%), 3$ out of 3 Yugoslavian $(100 \%)$ and $1(69 / 96)$ out of 5 Italian $(20 \%)$ strains hosted such extra bands; no bands were detectable in the remaining Italian, Argentinean and Romanian isolates (Figure 1).

\section{Chemicophysical nature of extrachromosomal elements}

The chemical nature of the extra-bands identified in D. helianthi isolates was defined by an RNAse A digestion performed on genomic DNAs: the enzymatic inefficacy with all $D$. helianthi samples proved that those extrachromosomal elements

Table 1. Diaporthe helianthi isolates

\begin{tabular}{|c|c|c|}
\hline Isolate & Origin & Source* \\
\hline $1 / 96$ & Argentina & DAPP \\
\hline $2 / 96$ & former Yugoslavia & CBS 592.81 \\
\hline $3 / 96$ & Italy & CBS 187.87 \\
\hline $4 / 96$ & Romania & DCDSL \\
\hline $5 / 96$ & Argentina & DAPP \\
\hline $6 / 96$ & Argentina & DAPP \\
\hline $7 / 96$ & France & DAPP \\
\hline $8 / 96$ & France & DAPP \\
\hline $9 / 96$ & Italy & DAPP \\
\hline $10 / 96$ & Italy & DAPP \\
\hline $11 / 96$ & former Yugoslavia & DAPP \\
\hline $68 / 96$ & Italy & DAPP \\
\hline $69 / 96$ & Italy & DAPP \\
\hline $70 / 96$ & former Yugoslavia & IMI 313865 \\
\hline $101 / 96$ & France & IMI 318861 \\
\hline $102 / 96$ & France & IMI 313866 \\
\hline $769 / 00$ & France & INRA 95006 \\
\hline $770 / 00$ & France & INRA 95007 \\
\hline $771 / 00$ & France & INRA 95015 \\
\hline $772 / 00$ & France & INRA 95010 \\
\hline $773 / 00$ & France & INRA 95016 \\
\hline $774 / 00$ & France & INRA 95044 \\
\hline $775 / 00$ & France & INRA 95042 \\
\hline $776 / 00$ & France & INRA 95051 \\
\hline $777 / 00$ & France & INRA 95084 \\
\hline $778 / 00$ & France & INRA 95100 \\
\hline
\end{tabular}

DAPP: Dip. Arboricoltura e Protezione delle Piante, University of Perugia, Italy; CBS: Centralbureau Schimmelcultures Baarn; DCDSL: Dip. Coltivazione e Difesa Specie Legnose "G.Scaramuzzi", University of Pisa, Italy; IMI: International Mycological Institute; INRA: Institut National de la Recherche Agronomique.

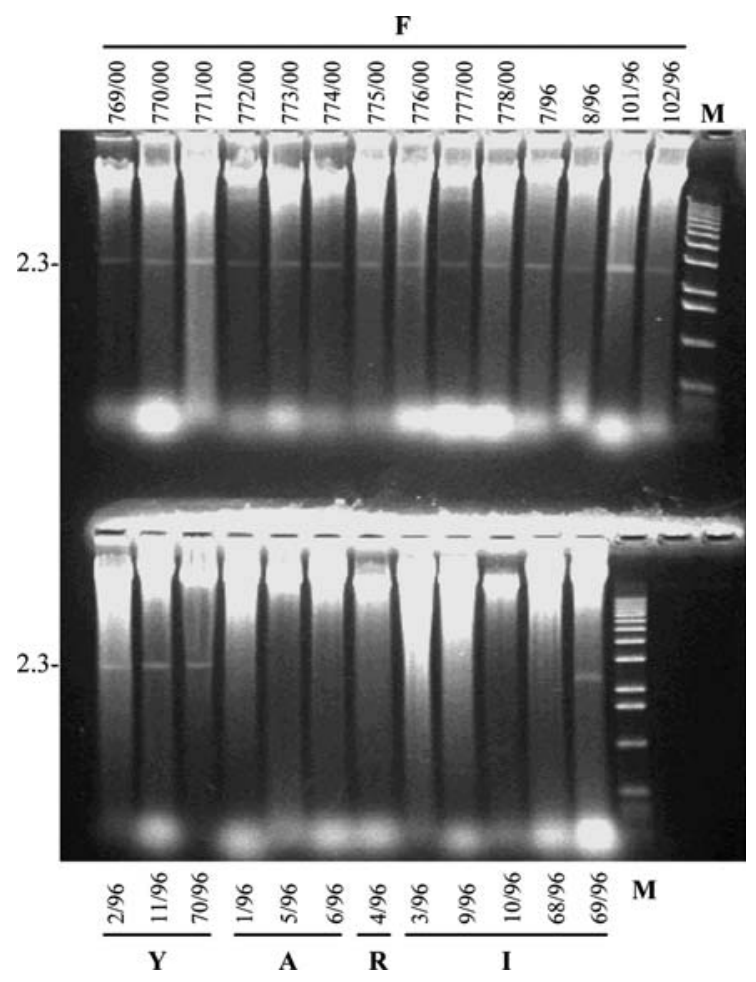

Figure 1. Electrophoresis of D. helianthi total genomic DNAs. F: French, Y: Yugoslavian, R: Romanian, A: Argentinean, I: Italian isolates. M: $1 \mathrm{~kb}$ DNA Ladder marker. On the left side the molecular size $(\mathrm{kbp})$ of extra-bands.

were plasmid DNA (data not shown). Their physical nature was then assayed: all 18 genomic DNAs of the $D$. helianthi isolates harbouring plasmids underwent a specific DNA exonuclease treatment in order to define the circular or linear structure of the plasmid molecules. Preliminary evidence, obtained using III-exonuclease, which specifically digests $3^{\prime}$ free ends of DNA molecules, suggested a circular structure of the plasmids, since the enzyme did not cut them. Further tests were then carried out performing a previous proteinase $\mathrm{K}$ incubation, followed by III-exonuclease digestion, since either covalently bound proteins or secondary structures on free ends may interfere with exonuclease activity [41]. The removal of proteins indeed allowed the DNA exonucleases to work on all plasmid molecules, proving their definitively linear structure (Figure 2).

\section{Molecular relatedness of plasmids}

In order to provide a probe for the Southern analysis of the plasmid molecules, one French 


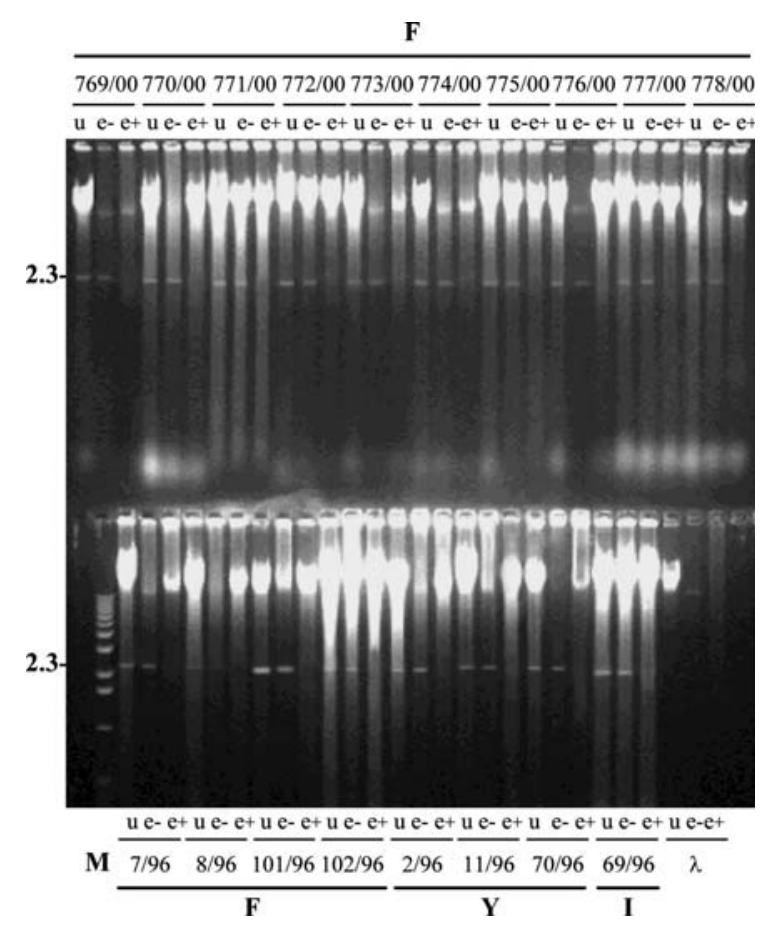

Figure 2. III-Exonuclease digestion of $D$. helianthi total genomic DNAs with $(\mathrm{e}+)$ and without $(\mathrm{e}-)$ a previous treatment by proteinase K. Untreated DNAs as control (u). Isolates and DNA marker as in Figure $1 ; \lambda$ : phage DNA as a control.

D. helianthi isolate $(101 / 96)$ was selected for plasmid purification, because of the most abundant plasmid in total DNA and of its geographic origin. The purified plasmid DNA was named plasmid $\mathrm{F}$ and used as a probe in Southern hybridisation experiments on total genomic DNAs derived from all $26 \mathrm{D}$. helianthi isolates. Molecular hybridisation showed a specific recognition of all French and Yugoslavian plasmids, while no signal was evident on the Italian plasmid (Figure 3).
These data suggest a molecular relatedness among all plasmids occurring in French and Yugoslavian isolates and a molecular divergence for the plasmid present in the Italian 69/96 isolate.

\section{Mitochondrial localisation of plasmid $F$}

The intracellular localisation of plasmid $\mathrm{F}$ was explored by isolating mitochondria and mtDNA (mitochondria DNA) from mycelium obtained from the French strain 101/96. Isolated mitochondria were treated with DNAse to remove possible residual genomic DNA and lysed for mtDNA extraction (sample $\mathrm{M}$ ); a fraction of whole mitochondria not DNAse treated was either kept as a negative control for mtDNA (M0) or lysed to exclude genomic DNA contamination (M1). As a test of the mtDNA restriction pattern, fractions of every sample were digested by KpnI. The electrophoretic profiles showed no contamination by genomic DNA (no DNA in M0, correspondence between $\mathrm{M}$ and $\mathrm{M} 1$, discrete bands pattern in restricted $\mathrm{mk}$ ) and revealed a $2.3 \mathrm{~Kb}$ band, missing $K p n \mathrm{I}$ sites being invariant after $K p n \mathrm{I}$ restriction (Figure 4a). A Southern blot experiment was performed on the same gel, using the plasmid $\mathrm{F}$ as a probe: the hybridisation pattern clearly showed a specific recognition of the mtDNA extra band in all lysed samples M and M1 (Figure 4b). This result confirms the correspondence between the mtDNA extra band and the plasmid F, thus conclusively demonstrating its mitochondrial localisation. It is noteworthy that no significant hybridisation appears in any mtDNA, indicating that plasmid $\mathrm{F}$ does not derive from mitochondrial rearrangements and may be considered as a true plasmid.

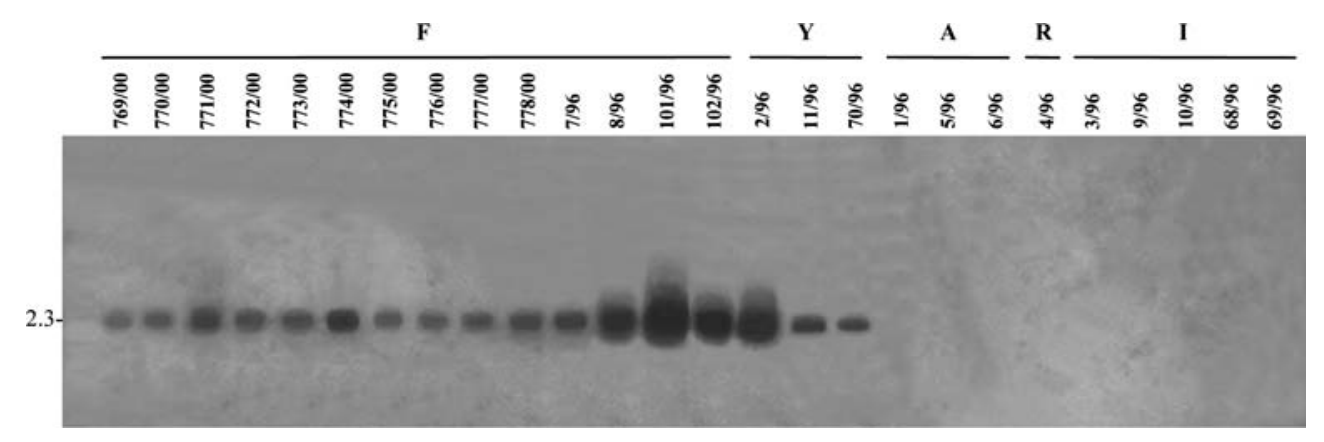

Figure 3. Southern blot hybridisation of $D$. helianthi total genomic DNAs with labelled plasmid $\mathrm{F}$ as a probe. D. helianthi isolates as in Figure 1. On the left side the molecular size (kbp) of plasmids. 


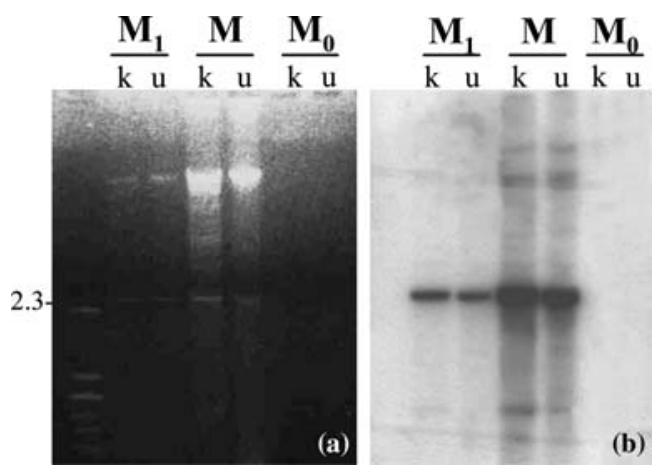

Figure 4. (a) MtDNA of a French isolate (101/96), treated (M) and not treated $\left(\mathrm{M}_{1}\right)$ by DNAse; not lysed mitochondria $\left(\mathrm{M}_{0}\right)$. $K p n I$ restricted (k). (b) Southern blot analysis of mitochondrial DNAs (as in (a)) hybridised with labelled plasmid $\mathrm{F}$ as a probe.

\section{Restriction mapping of plasmid $F$ and RFLP analysis}

A partial restriction map of plasmid $\mathrm{F}$ was established in order to further characterise the molecule. A sample of purified plasmid $\mathrm{F}$ was digested by several restriction enzymes: ApaI, EcoRI, HaeIII, Hsp92II, MspI, RsaI, PstI, SacI, SalI and CfoI. Since the amount of purified DNA after restriction was too low to be detectable on gel, DNAs underwent a Southern hybridisation experiment to enhance the electrophoretic profile (Figure 5). Restriction patterns of the plasmid $\mathrm{F}$ showed no cutting sites for ApaI, EcoRI, PstI, SacI and SalI,

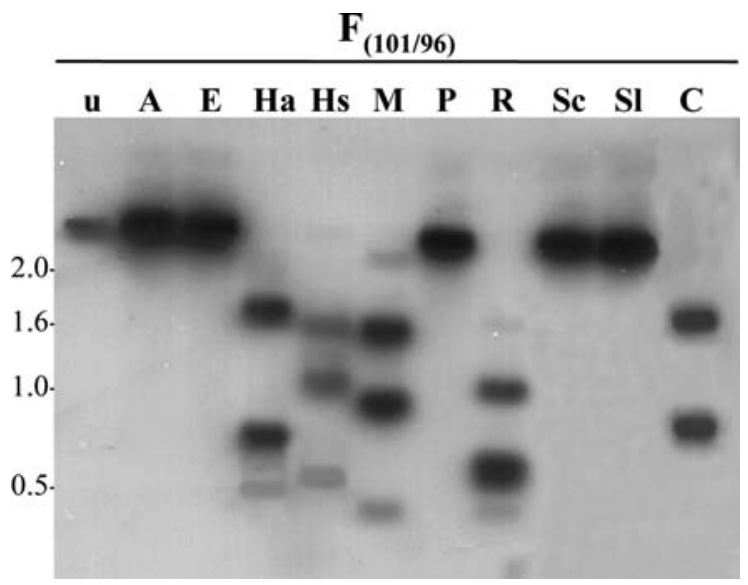

Figure 5. Restriction map of plasmid F. Purified plasmid DNA, restricted by ApaI (A), EcoRI (E), HaeIII (Ha), Hsp92II (Hs), MspI (M), PstI (P), RsaI (R), SacI (Sc), SalI (SI), CfoI (C) or uncut $(\mathrm{u})$, hybridised with plasmid $\mathrm{F}$ as a probe. DNA molecular sizes (kbp) on the left. while HaeIII, Hsp92II, MspI, RsaI and CfoI produced a multiple (two or three) bands profile, revealing the presence of such sites in the molecule. Based on this restriction map, an RFLP analysis was performed on genomic DNAs extracted from all $D$. helianthi isolates and digested by $M s p \mathrm{I}$, HaeIII, Hsp92II and CfoI to test molecular variability among all $D$. helianthi plasmids. Electrophoretic patterns were matched with plasmid $\mathrm{F}$ as a probe in a Southern blot experiment (Figure 6). Hybridisation patterns confirmed the molecular homogeneity of all plasmids present in French and Yugoslavian isolates.

\section{Discussion}

The economic losses for sunflower cultures caused in Europe by the pathogen Diaporthe helianthi, first recorded in the former Yugoslavia [19], induced several research groups in the afflicted countries to conduct studies on that system. First epidemiological analysis revealed different incidence levels of the disease, the stem canker, which occurred on the host based on geographic location: heavy damages were reported in the former Yugoslavia [42] and in France [21], whereas in

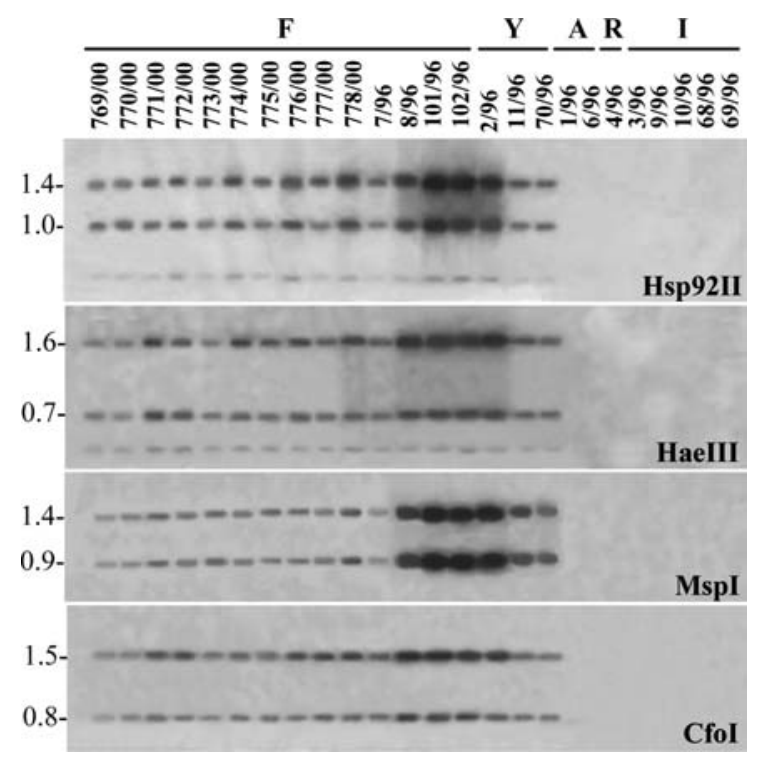

Figure 6. RFLP profiles of D. helianthi total genomic DNAs probed to labelled plasmid F. F: French, Y: Yugoslavian, R: Romanian, A: Argentinean, I: Italian. Relative restriction enzymes are in the right corner of each blot. On the left side DNA molecular sizes (kbp). 
Italy the pathogen is only sporadically found, in spite of conducive climatic conditions [24, 43].

Previous investigations were aimed at $D$. helianthi intraspecific variability and were based on morpho-physiological, biological and genetic characters [26, 27], host cultivars/pathogen isolates interaction [28], molecular genotypic and phenotypic features [29]. These studies all examined populations within the Diaporthe/Phomopsis helianthi complex from countries where the disease caused heavy damages. The first investigation dealing with a direct comparison between Italian and foreign $D$. helianthi isolates showed differences in the fungal population under study that correlated to geographic origin [30]. Therefore, it was evaluated the pathogen's molecular intraspecific variability in relation to its geographic origin, to disclose different possible genetic biotypes occurring in Italian populations, which may be responsible for the different epidemiological behaviour. Twenty-six D. helianthi isolates, collected from various countries (France, former Yugoslavia, Argentina, Romania and Italy), were explored by several approaches [44]: comparison of ribosomal (IGS and ITS) and mitochondrial sequences [31, 32], RAPD analysis [33], phenotypic (isoenzymatic) patterns [34] and amplification of a nuclear coding region [35]. Despite the sample's limited size, it did represent different regions in each country and, with respect to Italy, included every available Italian strain. Furthermore, the results obtained by these multi-approach investigations were strengthened by the convergence of a trend, in which all French and Yugoslavian isolates clustered together, while all Italian isolates appeared highly heterogeneous.

This investigation was planned to identify and to characterise, in the same set of isolates, extrachromosomal genetic determinants. It aimed at confirming the existence of homogeneous clusters on the basis of genetic markers, that significantly differ from those used in previous studies and at verifying the presence of plasmids, that may possibly modify the physiology of the pathogen in fungal populations deriving from countries greatly affected by stem canker epidemics. Extrachromosomal elements, all about $2.3 \mathrm{~kb}$ in size, appeared in most isolates: in every French and Yugoslavian and in one Italian. A chemicophysical analysis disclosed their DNA plasmidic nature with a linear conformation. The need of a proteinase treatment for DNA exonucleases' successful digestion implied that proteins associate with the ends of these molecules, making them resistant to enzymatic attacks. In many linear plasmids, terminal inverted repeats (TIR) involved in transcription or replication mechanisms have been observed, usually with covalently linked proteins, as reported in certain viral DNAs for priming of replication [4]. One plasmid purified from a French isolate (plasmid F) underwent further investigation. Its intracellular localisation was checked and it resulted to be mitochondrial and without any significant homology with mtDNA as a true plasmid, i.e. not of mitochondrial genome derivation. In order to check its specificity, plasmid $\mathrm{F}$ was used as a probe in Southern hybridisation experiments against total DNAs derived from all $26 \mathrm{D}$. helianthi isolates. The probe recognised all plasmids harboured by French and Yugoslavian isolates, whereas it detected no hybridisation signal corresponding to the plasmid hosted by the Italian strain. Apparently the first group of plasmids, with the interesting exception of the Italian plasmid, shared a molecular convergence. In order to further investigate the molecular specificity of plasmid $\mathrm{F}$ in relation to the geographic origin, an RFLP analysis involving multi-cutting enzymes was established with genomic DNAs derived from all isolates: hybridisation patterns were identical for all French and Yugoslavian plasmids, proving an internal similarity among these molecules.

The results presented here demonstrate that the entire body of French and Yugoslavian isolates contain plasmids which are not detectable in Italian isolates, emphasizing the diversity between the two fungal populations, as already shown by various tools [44]. Furthermore all plasmids hosted by French and Yugoslavian isolates strongly relate to each other and, within the sample of D. helianthi isolates under study, they may represent genetic markers correlated to that geographic cluster. In this context, it is interesting to note that isolates harbouring similar plasmids derive from countries where the disease caused by the pathogen is epidemic. The occurrence of related plasmids exclusively in such $D$. helianthi populations addresses more issues concerning their transmission within the population. Data are available in studies on both maternal inheritance through vertical transmission of mitochondrial plasmids [45] and the mobility of plasmids within a species due to horizontal transmission between somatic cells [46]. 
There is very little information about the existence of a vegetative incompatibility system in $D$. helianthi $[30,34]$, but all data suggest it is widespread among isolates, independent of their geographic origin. In $D$. helianthi, sexual reproduction plays a basic role in host infection, since primary infection occurs through ascospores; it therefore makes more sense to conceive plasmid diffusion via sexual reproduction. Then a question arises regarding plasmid distribution: is it a consequence of genetic variability or is it at the origin of this diversity?

Positive effects due to the presence of a plasmid in a fungal host are reported in Podospora anserina and in Fusarium oxysporum. In P. anserina, the plasmid pAL2-1 occurs only in a long living strain (AL2) and has proved to be involved in the expression of such a phenotype [10]. A natural Fusarium oxysporum strain is resistant to nitrofuran and a loss of drug resistance correlates to a loss of a circular plasmid; thus, the plasmid improves fungal fitness, since the strains that are sensitive to nitrofuran are unable to grow on polypectate as a sole carbon source [15]. In our system, where the genetic variability of $D$. helianthi correlates to the presence/absence of plasmids and to epidemiology, plasmids may confer better fitness to French and Yugoslavian isolates.

In conclusion, this investigation not only confirms the genetic diversity already found in $D$. helianthi through different means, but it also opens new questions and allows speculation on the origin and evolution of this species, which may contribute to the knowledge of the epidemiology of sunflower stem canker.

\section{Acknowledgements}

Research supported by Italian MURST, National Projects "Diaporthe helianthi - sunflower: study of a pathosystem" and "Diaporthe helianthi: a potential risk for sunflower in Italy".

\section{References}

1. Griffiths AJF. Natural plasmids of filamentous fungi Microbiol. Rev. 1995; 59(4): 673-685.

2. Stohl LL, Lambowitz AM. Construction of a shuttle vector for the filamentous fungus Neurospora crassa Proc. Natl. Acad. Sci. USA. 1983; 80: 1058-1062.
3. Barreau C, Iskandar M, Turcq B, Javerzat JP. Use of a linear plasmid containing telomeres as an efficient vector for direct cloning in the filamentous fungus. Podospora anserina Fungal. Genet. Biol. 1998; 25: 22-30.

4. Kempken F. Plasmid DNA in mycelial fungi. In: Kuck U, ed. The Mycota Vol. II Genetics and Biotechnology, Heidelberg: Springer-Verlag KG, 1995: 169-187.

5. Rubidge $\mathrm{T}$. The structure and function of plasmid in filamentous fungi Handbook Appl. Mycol. Fungal Biotechnol. 1992; 4: 243-258.

6. Kempken F, Hermanns J, Osiewacz HD. Evolution of linear plasmids J. Mol. Evol. 1992; 35: 502-513.

7. Kück U. Mitochondrial DNA rearrangements in Podospora anserina Exp. Mycol. 1989; 13: 111-120.

8. Nargang FE. Fungal mitochondrial plasmids Exp. Mycol. 1985; 9: 285-293.

9. Griffiths AJF. Fungal senescence Annu. Rev. Genet. 1992; 26: 351-372.

10. Hermanns J, Asseburg A, Osiewacz HD. Evidence for a life span-prolonging effect of a linear plasmid in a longevity mutant of Podospora anserina Mol. Gen. Genet. 1994; 243: 297-307.

11. Gobbi E, Carpanelli A, Firrao G, Locci R. The Cryphonectria parasitica plasmid pUG1 contains a large ORF with motifs characteristic of family B DNA polymerases Nucl. Acids Res. 1997; 25: 3275-3280.

12. Gobbi E, Rekab D, Locci R. Mitochondrial plasmids of the $\mathrm{pCp}$ family are spread worldwide in Cryphonectria parasitica populations Mycol. Res. 2002; 106(12): 1408-1416.

13. Martini G, Grimaldi G, Guardiola J. Extrachromosomal DNA in phytopathogenic fungi. In: Boyer HW, Nicosia S, eds. Genetic Engineering, Elsevier, Amsterdam, 1978: 187-200.

14. Hashiba T, Homma Y, Hyakumachi M, Matsuda I.. Isolation of a DNA plasmid in the fungus Rhizoctonia solani J. Gen. Microbiol. 1984; 130: 2067-2070.

15. Guardiola J, Grimaldi G, Constantino P, Micheli G, Cervone F. Loss of nitrofuran resistance in Fusarium oxysporum is correlated with loss of a $46.7 \mathrm{~kb}$ circular DNA molecule J. Gen. Microbiol. 1982; 128: 2235-2242.

16. Kistler HC, Leong SA. Linear plasmid-like DNA in the plant pathogenic fungus Fusarium oxysporum f. sp. conglutinans J. Bacteriol. 1986; 167: 587-593.

17. Hiratsuka $K$, Namba $S$, Yamashita $S$, Tsuchizaki $T$. Linear plasmid DNA in Pyrenophora graminea, a fungal pathogen of barley Proc. Jpn. Acad. 1989; 65: 42-44.

18. Duvell A, Hessberg-Stutzke H, Oeser B, Rogmann-Backwinkel P, Tudzynski P. Structural and functional analysis of mitochondrial plasmids in Claviceps purpurea Mol. Gen. Genet. 1988; 214: 128-134.

19. Mihaljčević M, Petrov M, Muntañola-Cvetković M. Phomopsis sp., a new parasite of sunflower in Yugoslavia Savr. Poljoprivreda 1980; 28: 531-539.

20. Pentericci S. La diffusione della Phomopsis nei paesi CEE e varietà resistenti Sementi Elette. 1995; 41(3-4): 38-39.

21. Laville J. Cahier technique tournesol: maladie. Paris: CETIOM, 1986.

22. Diaz FA, Ortegon MA. Influence of sunflower stem canker (Diaporthe helianthi) on seed quality and yield during seed development Helia. 1997; 20: 57-62. 
23. Zazzerini A, Tosi L, Losavio N. Rilievi fitopatologici su varietà di girasole a confronto nel 1987 L'Informatore Agrario. 1988; 13: 85-88.

24. Battilani P, Rossi V, Girometta B, Delos M, Rouzet J, André N, Esposito S. Estimating the potential development of Diaporthe helianthi epidemics in Italy EPPO Bull. 2003; 33: 427-431.

25. Acimovic M, Štrasser N. Phomopsis sp. a new parasite in sunflower Helia. 1981; 4: 43-58.

26. Muntañola-Cvetković M, Vukojevic J, Mihaljcevic M. Cultural growth patterns and incompatibility reactions in Diaporthe and Phomopsis populations J. Phytopathol. 1996; 144: 285-295.

27. Vukojević J, Mihaljčević M, Franić Mihaijlović D. Variability of Phomopsis populations in sunflower (Helianthus annuus L.) Helia. 2001; 24: 69-76.

28. Viguié A, Vera F, Tourvieillede Labrouhe D. Interactions between French isolates of Phomopsis/Diaporthe helianthi Munt.-Cvet. et al. and sunflower (Helianthus annus L) genotypes. Eur. J. Plant Pathol. 1999; 105: 693-702.

29. Says-Lesage V, Roeckel-Drevet P, Viguié A, Tourvieille J, Nicolas P, Tourvieillede Labrouhe D. Molecular variability within Diaporthe/Phomopsis helianthi from France Phytopathology. 2002; 92: 308-313.

30. Vannacci G, Pecchia S, Cacciola SO, Zazzerini A. Studi sulla variabilità di Diaporthe helianthi Petria. 1996; 6: 264 265.

31. Pecchia S, Mercatelli E, Vannacci G. Intraspecific diversity within Diaporthe helianthi: evidence from rDNA intergenic spacer (IGS) sequence analysis Mycopathologia. 2004; 157: 317-326.

32. Rekab D, Del Sorbo G, Reggio C, Zoina A, Firrao G. Polymorphisms in nuclear rDNA and mtDNA reveal the polyphyletic nature of isolates of Phomopsis pathogenic to sunflower and a tight monophyletic clade of defined geographic origin Mycol. Res. 2004; 108: 393-402.

33. Pollastro S, Giampaolo C, Natale P, Abbatecola A, Faretra F. RAPD analysis in Diaporthe helianthi. Proceedings of the 6th European Conference on Fungal Genetics, Pisa, Italy, Vannacci G, Sarrocco S, eds. 2002: 431.

34. Raudino F, Pappalardo P, LiDestri Nicosia MG, Pennisi AM, Cacciola SO. Studio della variabilità fenotipica di isolati di Diaporthe/Phomopsis helianthi Notiziario sulla Protezione delle Piante. 2002; 15: 415-416.

35. Vergara M, Cristani C, Regis C, Vannacci G. A coding region in Diaporthe helianthi reveals genetic variability among isolates of different geographic origin Mycopathologia. 2004; 158: 123-130.
36. Vergara M, Capasso T, Gobbi E, Vannacci G. Presence of plasmids in Diaporthe helianthi isolates from different geographic origin. Proceedings of the 9th Annual Meeting of SIPaV, Roma, Italy. J. Plant Pathol. 2002; 84(3): 198.

37. Haegi A, Aragona M, Vannacci G, Delogu G, PortaPuglia A. Phytotoxic compounds in culture filtrates of Pyrenophora graminea Petria. 1994; 4: 181-192.

38. Kim WK, Muhe W, Hausner G, Klassen GR. Isolation of high molecular weight DNA and double-stranded RNAs from fungi Can. J. Bot. 1990; 68: 1898-1902.

39. Taylor JW, Natvig D. Zoosporic fungi in teaching and research. In: Fuller MS, Jaworski A eds. Southeastern Athens GA, 1987: 252-258.

40. Sambrook J, Fritsch EF, Maniatis T. In: Molecular Cloning. A Laboratory Manual. Cold Spring Harbor Laboratory Press, NY, USA, 1989.

41. Cong Y, Yarrow D, Li Y, Fukuhara H. Linear DNA plasmids from Pichia etchellsii, Debaryomyces hansenii and Wingea robertsiae Microbiology. 1994; 140: 1327 1335.

42. Mihaljčević M, Muntañola-Cvetković M, Vukojević J, Petrov M. Source of infection of sunflower plants by Diaporthe helianthi in Yugoslavia Phytopathol. Z. 1985; 113: 334-342.

43. Rossi V, Girometta B. Dynamic of sunflower phenology in relation to susceptibility toward Diaporthe helianthi $\mathbf{J}$. Plant Pathol. 2001; 83: 242.

44. Vannacci G, Cacciola SO, Del Sorbo G, Faretra F, Firrao G, Pecchia S, Pollastro S, Raudino F, Reggio C, Rekab D, Vergara M. Analysis of genetic variability in the phytopathogenic fungus Diaporthe helianthi. Proceedings of the 6thEuropean Conference on Fungal Genetics, Pisa, Italy, Vannacci G, Sarrocco S, eds. 2002: 398.

45. Griffiths AJF, Bertrand H. Unstable cytoplasms in Hawaiian strains of Neurospora intermedia Curr. Genet. 1984; 8: 387-398.

46. May G, Taylor JW. Independent transfer of mitochondrial plasmids in Neurospora crassa Nature. 1989; 359: 320-322.

Author for correspondence: Dr. Mariarosaria Vergara, Dipartimento di Coltivazione e Difesa delle Specie Legnose "G. Scaramuzzi", Sez. Patologia Vegetale, Via del Borghetto 80, 56124 Pisa, Italy

Phone + 39-050-571556; Fax + 39-050-543564

E-mail: rvergara@agr.unipi.it 